\title{
Developments
}

\section{The Constitutionality of $\S 89 a$ of the German Criminal Code (StGB) and the Concept of a Serious Act of Violent Subversion: The German Federal Court of Justice (Bundesgerichtshof), Judgement of $8^{\text {th }}$ May 2014 - 3 StR}

\section{$243 / 13$}

\author{
By Christopher Ohnesorge, Julia Wilkes, Marius Eichfelder, Jinnus Rastegar, \\ Matthias Derra \& Julia Balmer*
}

\begin{abstract}
As a reaction to the increasing terrorist threat in Europe, the German Parliament (Bundestag) passed a law penalizing the preparation of terrorist acts endangering the state: $\S 89$ a German Criminal Code (StGB). ${ }^{1}$ The Regional Court of Frankfurt am Main (LG Frankfurt) was the first to apply this section to a case where a young man was accused of building a pipe bomb. Upon his conviction, the defendant appealed to the German Federal Court of Justice $(\mathrm{BGH}){ }^{2}$, claiming $\S 89$ a StGB to be unconstitutional. The BGH reviewed whether the statute was in conformity with the principles of the German Constitution $(\mathrm{GG}){ }^{3}$ including the principle of legal certainty and appropriateness. It held that these principles were fulfilled, if stricter requirements are applied regarding the mens rea in order to counterbalance the broad actus reus. It decided that the Regional Court had not fulfilled this particular requirement and quashed the conviction insofar. This case and $\S 89 a$ StGB caused ripples amongst legal scholars, especially due to the unusual penalization of preparatory acts and the broad scope of the statute's application. This case also produced an unprecedented change within the judge's bench.
\end{abstract}

\footnotetext{
* All authors are students of law at the Friedrich-Alexander Universität Erlangen-Nürnberg, participating in an extracurricular advanced legal English program. The authors wish to thank Kevin Pike and Prof. Christoph Safferling for their help and this opportunity.

1 Strafgesetzbuch [StGB] [German Penal Code], § 89a, translation at http://www.gesetze-iminternet.de/englisch_stgb/index.html.

2 Bundesgerichtshof [BGH] [Federal Court of Justice] May 8, 2014, 3 StR 243/13 NEUE JURISTISCHE WOCHENSCHRIFT [NJW] 3459 (Ger.) [hereinafter Judgment of May 8, 2014].
}

${ }^{3}$ Grundgesetz [GG], translation at http://www.gesetze-im-internet.de/englisch_gg/index.html. 


\section{A. Introduction}

Threats from international terrorism remain prevalent and potent. According to the Bundestag, when the legislation that included § 89a was first included in the StGB, the risk of serious acts of violent subversion in Europe was, in particular, illustrated by the attacks in London and Madrid, the thwarted attacks on airlines in London, and by the suitcase bombs discovered in regional trains in Dortmund and Koblenz. In recent history, Germany has suffered from terrorist attacks, for example the suicide bombing in Ansbach. Specifically, the significance of internet platforms - which provide for content sharing that guides those committing terrorist attacks-is increasing. Moreover, terrorist instruction camps where perpetrators are instructed have gained relevancy regarding the preparation of terrorist attacks. These kinds of preparation techniques, however, could formerly only be prosecuted if there was proof of one of the following: the offender is a member of a "terrorist group" ( $\S 129$ a StGB), there is conspiracy or an attempt to incite a terrorist attack ( $\$ 30 \mathrm{StGB}$ ), or such an attack has already been attempted beyond mere planning or preparation ( $\S \S 22,23 \mathrm{StGB}$ ).

The preparation of violent subversive acts incorporates serious danger, particularly considering the short time period between preparation and execution. Besides that, organizational structures of terrorist groups perpetually vary, for example al-Qaeda's hierarchical structures have become decentralized. As a result, § 129a StGB does not sufficiently protect against preparatory acts that precede terrorist attacks.

Therefore, the StGB was amended by including inter alia $\S 89 a$, which makes merely the preparation of serious violent subversive acts an offense when the perpetrator commits the enumerated actions embracing (1) instructing another person or receiving instruction for instance in a terrorist camp, (2) producing, obtaining, storing or supplying relevant weapons, substances, or devices and facilities, or (3) obtaining or storing objects or substances essential for the production of the weapons and substances mentioned above. Although the punishment for mere preparation is unusual, it is not new in German criminal law. ${ }^{4}$

In addition, the scope of $\S 89$ a also includes acts that are committed in another country in order to cope with the fact that terrorism often involves international networks.

4 See Strafgesetzbuch [StGB] [German Penal Code], $\S \S 80,83,149,202 \mathrm{c}, 275,310$, translation at http://www.gesetze-im-internet.de/englisch_stgb/index.html. 


\section{B. Circumstances of the Decision}

After receiving German citizenship in 2009, the Afghan-born defendant, K, started studying mechanical engineering. In 2010, $\mathrm{K}$ gained the impression that the Western media coverage was generally blaming Muslims for terrorist attacks around the world and thus branding all Muslims terrorists. Subsequently, $\mathrm{K}$ began to feel hatred towards Western civilization and a desire for vengeance, because the Western civilization was, in his view, fighting and oppressing the Muslim population.

$\mathrm{K}$ began to do research on the internet, focusing on the Islamist-Jihadist area of Islam and especially the theological admissibility of armed Jihad, its territorial applicability, suicide and martyrdom, and collateral damage in Muslim civilization. In Summer 2010, the 24year-old defendant downloaded and read the Jihad propaganda magazine "Inspire," which contained the article "How to Build a Bomb in the Kitchen of Your Mom." This article gave instructions on how to use readily available materials to build a pipe bomb capable of killing up to ten people.

In 2011-at the latest-the defendant came to the decision to build a pipe bomb as described in the aforementioned article. For that purpose, K rented a room in January 2011 and started the subsequent purchase of any required ingredients. This included nearly 200 boxes of matches, fireworks, metal pipes including seal caps, batteries, sugar, a chain of fairy lights, three alarm clocks, a cell phone, and sodium chlorate. In February 2011, K successfully tested igniting the explosive powder he had mixed from the matchstick heads and the black powder collected from the fireworks. The ingredients $\mathrm{K}$ collected were sufficient to construct a pipe bomb with a lethal impact radius of nine meters.

On February $13,2011, \mathrm{~K}$ accidently set off an explosion while grinding flares in a mixer. He inflicted second-degree burns on his face and arms. After being admitted to a hospital he was questioned by police. $K$ was discharged from the hospital on March 5, 2011 and was temporarily homeless. Despite police observation, $\mathrm{K}$ managed to take a flight to Pakistan, where he stayed with his wife's family. On May 8, 2011, a warrant was issued for K's arrest. He returned to Germany on December 22, 2012 and was arrested immediately.

The LG Frankfurt convicted $\mathrm{K}$ and sentenced him to a term of three years imprisonment for the preparation of a serious violent offense endangering the state pursuant to $\S 89$ a StGB. This also included a conviction for negligently causing an explosion pursuant to $\S 308 \mathrm{StGB}$. The court based its conviction mainly on the information gained from the evaluation of the materials seized from the room rented by $\mathrm{K}$ and the comprehensive statement $\mathrm{K}$ gave the police.

The defendant appealed the decision and claimed that § 89a StGB was unconstitutional. 


\section{Decision of the BGH}

The $B G H$ addressed the question of whether $\S 89$ a StGB was unconstitutional. ${ }^{5}$ In the end, it partially set aside the verdict of the LG Frankfurt.

In the following Sections, (I.) the court's scrutiny of the constitutionality of $\S 89 a$ StGB will be addressed, followed by (II.) its application to the case, and (III.) the unprecedented conflict of interest in the case.

\section{Constitutionality of $\S 89 a$ StGB}

The court scrutinized whether $\S 89$ a StGB is in line with the constitutional principles of (1) legal certainty and (2) appropriateness.

\section{The Principle of Legal Certainty (Bestimmtheitsgebot)}

\subsection{Significance}

Pursuant to Article 20 (3) GG, the precedence of the constitution pertains. ${ }^{6}$ This means that every law has to be in compliance with the GG. If this is not the case, the law will be invalid ab initio (from the beginning). ${ }^{7}$

One fundamental constitutional principle is the Bestimmtheitsgebot (principle of legal certainty). It is consistently a prohibition of analogy in the area of criminal law. ${ }^{8}$ In this respect, Article 103 (2) GG, which states that punishment is only constitutional if the criminality of the act is defined by law before the commission, is a peculiarity of the general Bestimmtheitsgebot as a part of the Rechtsstaatsprinzip (rule of law). ${ }^{9}$

The principle of legal certainty includes the legislative obligation to clarify substantial questions of culpability or exemptions from punishment. Therefore, the legislature is

\footnotetext{
${ }^{5}$ See Judgment of May 8, 2014, supra note 2, at para. 1.

${ }^{6}$ See Hans D. Jarass \& Bodo Pieroth, Jarass/Pieroth Grundgesetz: GG, Art. 20 para. 32 (13th ed. 2011).

7 See Bundesverfassungsgericht [BVerfGE] [Federal Constitutional Court], 1 BvL 83/86, 1 BvL 24/88, 1991, NEUE JURISTISCHE WOCHENSCHRIFT [NJW] 1602.

8 See Bundesverfassungsgericht [BVerfGE] [Federal Constitutional Court], 2 BvR 15/62, 1962, LMRR 14; Bundesverfassungsgericht [BVerfG] [Federal Constitutional Court], 2 BvR 2273/06, 2007, NEUE JURISTISCHE WOCHENSCHRIFT [NJW] 1666.

${ }_{9}^{9}$ See Bundesverfassungsgericht [BVerfGE] [Federal Constitutional Court], 2 BvR 234/87, 2 BvR 1154/86, 1989, NEUE JURISTISCHE WOCHENSCHRIFT [NJW] 1663 (1665); see also Mark A. Zöller, Festschrift für Jürgen Wolter zum 70. Geburtstag, 503-06 (2013).
} 
committed to paraphrasing the conditions of criminal liability in such a precise way that the consequence and area of application of the criminal offense is distinguishable and determinable by an interpretation of the legal provision. ${ }^{10}$ The constitutional principles implying the obligation for legislators to take every substantial decision themselves are quite weighty, especially in the area of criminal law. Thus, the principle of legal certainty requests that the legislature captures statutory provisions as precisely as possible so the addressees of a provision may already distinguish through the wording if certain behavior is indictable. ${ }^{11}$ In borderline cases, where the punishability of a certain behavior may not be definite, the risk of punishment has to be at least foreseeable. ${ }^{12}$ This does not imply that every rule must be clarified down to the last detail. Rather, the legislator should remain in the position of meeting the multifarious requirements of life. ${ }^{13}$ Otherwise, there would be a risk that the principles become inflexible and casuistic and hence would not make the necessary adjustments over time in response to changing circumstances. A consequence of the abstractness of criminal provisions is uncertainty as to whether certain behavior constitutes a criminal offense is unavoidable. Accordingly, the principle of legal certainty by no means signifies the obligation of the legislator to outline any criterion in an exclusively comprehensive way. Rather it is legitimate to have recourse to past jurisdictions for an interpretation of the law. ${ }^{14}$

Accordingly, it is not possible to make a general assertion about how certain the legal criminal offense must be. Rather, the offense has to be viewed in its totality to ascertain whether the legislator has adhered to Article 103 (2) GG. With this, characteristics of the particular criminal offense have to be taken into consideration, such as circumstances leading to the statutory regulation as well as the norm addressees. ${ }^{15}$ At that point, the higher the threatened punishment is, the more precisely the legislature must determine the culpability requirements. ${ }^{16}$

\footnotetext{
${ }^{10}$ Jarass \& Pieroth, supra note 6, at Art. 103 para. 48.

11 See Wolfgang Mitsch, Vorbeugende Strafbarkeit zur Abwehr terroristischer Gewalttaten, NEUE JURISTISCHE WOCHENSCHRIFT [NJW] 209 (2015) (providing an evaluation from the perspective of practitioners).

12 See Bundesverfassungsgericht [BVerfG] [Federal Constitutional Court], 2 BvR 932/06, 2007, NeUE JURISTISCHE WOCHENSCHRIFT [NJW] 1666.

${ }^{13}$ See Bundesverfassungsgericht [BVerfG] [Federal Constitutional Court], 1 BvR 2150/08, 2010, NEUE JURISTISCHE WOCHENSCHRIFT [NJW] 47, para. 107.

${ }^{14}$ See Ronald Schmitz, Joecks/Miebach Münchener Kommentar zum StGB, §§ 242-45 (2nd ed. 2011).

${ }^{15}$ See, for e.g., Bundesverfassungsgericht [BVerfGE] [Federal Constitutional Court], 2 BvR 2559/08 i.a., 2010, NEUE JURISTISCHE WOCHENSCHRIFT [NJW] 3209.

${ }^{16}$ See Bundesverfassungsgericht [BVerfG] [Federal Constitutional Court], 2 BvL 11/85, 1987, NeUE JURISTISCHE WOCHENSCHRIFT [NJW] 3175.
} 
In the constellation examined here, the $B G H$ did not ask the Federal Constitutional Court $(B V e r f G)^{17}$ for a decision by means of a concrete review of the status in accordance with Article $100 \mathrm{GG}$, but rather took on a constitutional interpretation by itself.

\subsection{Application to $\S 89 a$ StGB}

The first condition for culpability is a serious act of violent subversion. The legal definition of $\S 89$ a (1) 2 StGB states that the preparatory act must intend to impair and actually be capable of impairing the existence or security of a state or of an international organization, or to abolish, rob of legal effect, or undermine constitutional principles of the Federal Republic of Germany. ${ }^{18}$ There are a significant number of terms which still need to be defined. Albeit, the legislature has explicitly seized on the wording of $\S 120$ of the German Courts Constitution Act $(G V G)^{19}$ and the case law relating thereto. ${ }^{20}$ Thereby, it was stated that the factual conditions had already been clarified by superior court decisions and access to the definitions in $\S 92 \mathrm{StGB}$ is available. ${ }^{21}$ The $B G H$ held that the text of the law ensures an interpretation of the regulation and consequently an apprehension of the content. ${ }^{22}$

Besides a serious act of violent subversion, one of the three different statutory criminal actions stipulated in $\S 89$ a (2) StGB must be performed. The statutory regulation contributes to a clearer distinction amongst indictable conduct and behavior which are not subject to prosecution. ${ }^{23}$

In the present case, the $B G H$ had to deal with $\S 89$ a (2) No. 1, 3 StGB, on which the conviction from the LG Frankfurt was based. The $B G H$ held that the aforementioned regulations are sufficiently concrete and that the legislature insofar adopted a wording

\footnotetext{
${ }^{17}$ Bundesverfassungsgericht.

18 See Strafgesetzbuch [StGB] [German Penal Code], $\S \S 211,212,239 a$ or 239b, translation at, http://www.gesetze-im-internet.de/englisch_stgb/index.html (having committed an offense according to such sections of StGB).

${ }^{19}$ Gerichtsverfassungsgesetz.

${ }^{20}$ See, e.g., Bundesgerichtshof [BGH] [Federal Court of Justice] 2001, 3 StR 378/00 NEUE JURISTISCHE WOCHENSCHRIFT [NJW] 1359, .

${ }^{21}$ See Regierungsentwurd [Cabinet Draft] Deutscher Bundestag: Druckashen [BT] 16/12428, 14.

22 See Judgment of May 8, 2014, supra note 2, at para. 3461.

23 See Strafgesetzbuch [StGB] [German Penal Code], translation at http://www.gesetze-iminternet.de/englisch_stgb/index.html (excluding $\S \S 80,83$ and 234a (3) StGB, which are restricting hereunto).
} 
similar to $\S 310$ (1) StGB. ${ }^{24}$ Concerning the prerequisite of special equipment required for the accomplishment of the deed, it is understood that a particularly technical apparatus and instruments, detonators, and other engineered products are included. Due to the subjects and substances listed, as well as the necessity of the conduct, a further ascertainment through the common legal interpretation methods is possible. Anyhow, the question arises whether everyday items are covered by $\S 89$ a (2) No. 3 StGB as well. A mobile phone, for example, may be indispensable for manufacturing a weapon. ${ }^{25}$ It is not apparent from a reading of $\S 89$ a (2) No. $3 \mathrm{StGB}$, however, that the legislator aimed to exclude items such as mobile phones and alarm clocks with the prerequisite of necessity. ${ }^{26}$. That is why it is particularly suggested to cover everyday items under No. 3 if their purpose of use is intentionally changed. ${ }^{27}$ Additionally, it is differentiated according to whether or not the possession of the item is socially accepted and therefore legally permitted. ${ }^{28}$ Everyday items are then crucial in terms of $\S 89$ a (2) No. $3 \mathrm{StGB}$, if all objects together represent an efficient weapon according to $\S 89$ (2) No. 1 StGB.

\section{Appropriateness of the Norm}

\subsection{Legitimate Legislative Purpose}

The Bundestag passed § 89a StGB in August 2009. It was argued that the already existing sections pertaining to terrorist threats were no longer sufficient for an effective prosecution. The objective was inter alia to ensure that preparatory actions of offenders that are unaffiliated with a terrorist organization would be punishable. ${ }^{29}$ The BGH deemed this pursued purpose unequivocally constitutional. ${ }^{30}$

\footnotetext{
${ }^{24}$ But see N. Gazeas, Leipold/Tsambikakis/Zöller, Anwaltskommentar zum StGB, § 89a para. 6, (1st ed. 2011) (offering critical commentary on this position).

${ }^{25}$ See Sternberg-Lieben, Schönke/Schröder, StGB Kommentar § 89a para. 15 (29th ed. 2014).

${ }^{26}$ See supra note 21, at para. 15; see J. Schäfer, Joecks/Miebach, Münchener Kommentar zum StGB § 89a para. 48 (2nd ed. 2011).

${ }^{27}$ See K. Backes, Der Kampf des Strafrechts gegen nicht-organisierte Terroristen, STV 654, para. 658 (2008).

${ }^{28}$ See R. Haverkamp, Verbrechen - Strafe - Resozialisierung: Festschrift für Heinz Schöch zum 70. Geburtstag am 20. August 2010 381, 392 (2010).

${ }^{29}$ See supra note 21 , at para. 1.

${ }^{30}$ See H.-U. Paeffgen, Kindhäuser/Neumann/Paeffgen § 89a StGB (2013) (opposing the notion that the de facto law includes the endangerment of all states, not just the BRD-which could be critical under international law).
} 


\subsection{Suitability (Geeignetheit) and Necessity (Erforderlichkeit) ${ }^{31}$}

Furthermore, the law had to be held suitable and necessary to attain this purpose, because it constitutes an infringement of Article 2 (1) and (2) GG. ${ }^{32}$

In relation to this aspect, the $B G H$ referred to the margin of discretion which the legislature possesses. ${ }^{33}$ Due to this prerogative, the court is not obliged to ascertain whether the enacted legislation is the most reasonable and purposeful option. Therefore, it can only be deemed unconstitutional if it is self-evident that the legislators have transgressed their boundaries, which was not the case. ${ }^{34}$

This substantiation has been criticized by voices in jurisprudential literature, presuming it to be superficial. Some reason that the court would even evade the most basic control and would leave almost unlimited leeway for the legislature. Whether the law was suitable at all is debatable, because it has not been established empirically that criminal law is the most adequate tool to combat terrorism. ${ }^{35}$

\subsection{Reasonability (Angemessenheit)}

Lastly, § 89a StGB shall fulfill the prerequisite of reasonability. A law will only be reasonable if its intensity and the way it afflicts the individual is not disproportionate to the protected basic right. ${ }^{36}$ Because no general rules exist, the reasonability of each law must be examined individually. This means that every aspect of the statute has to be considered critically. ${ }^{37}$ In this case, regarding $\S 89$ a StGB, five aspects need to be scrutinized particularly in the light of the German Constitution: (a) the high custodial sentence, (b) the criminalization of the preparation, (c) the question of whether the statute is an unlawful

${ }^{31}$ Geeignetheit means that the measure taken by the state must be appropriate to further or reach the intended aim, while Erforderlichkeit denotes that the measure must be the least severe in comparison to other options. See B. Grzeszick, Art. 20 GG-Kommentar, Maunz/Dürig, para. 112 (2016).

32 See Judgment of May 8, 2014, supra note 2, at para. 3459.

33 This margin of discretion cannot be fully scrutinized by the courts due to practical reasons. See Bundesverfassungsgericht [BVerfG] [Federal Constitutional Court], 2 BvL 43/92, 1994, NEUE JURISTISCHE WOCHENSCHRIFT [NJW] 1577 (commenting further regarding the margin of discretion).

${ }^{34}$ See Judgment of May 8, 2014, supra note 2, at para. 3459.

35 See M. Zöller, Die Vorbereitung schwerer staatsgefährdender Gewalttaten nach § 89 a StGB - wirklich nicht verfassungswidrig?, NSTZ 373 (2015).

${ }^{36}$ See S. Huster \& J. Rux, V. Epping/C. Hillgruber, Beck'scher Online-Kommentar zum Grundgesetz, Art. 20 para. 197 (26th ed. 2015).

37 See Judgment of May 8, 2014, supra note 2, at para. 3462. 
punishment of a criminal's attitude, (d) the constitutionality of the state security provision, and (e) the broad mens rea.

\section{a) The High Custodial Sentence}

As mentioned above, every aspect of the Angemessenheit must be judged by the right of Article 2 (2) 2 GG, which guarantees one's right to liberty. This basic right might be affected in an inappropriate way due to the high sentence mandated by $\S 89$ a StGB. Pursuant to this section, a perpetrator who prepares a terrorist act is liable to a term of imprisonment of six months to ten years. Even in minor cases, the sentence amounts to three months, in accordance with $\S 89$ a (5) StGB. It is left to the judge's discretion, however, whether and how to mitigate the sentence or even exempt a defendant from a punishment if the culprit shows remorse..$^{38}$ Hence, it is possible to adapt the sentence justly in each case. In addition, the prosecution service could theoretically eliminate the perpetrator from the enquiry if there is no significantly high level of guilt. Finally, in view of conceivable terrorist attacks aiming to murder hundreds of people, the maximum sentence of ten years seems proportional. ${ }^{39}$

\section{b) The Criminalization of the Preparation of a Crime}

Apart from the high custodial sentence, it could be argued that $\S 89$ a StGB must be rendered unconstitutional because it criminalizes the preparation of a crime which occurs prior to the actual attempt. ${ }^{40}$ This system applies to other areas of German criminal law as well: for instance, $\S \S 80,83,87,149$, and $310 \mathrm{StGB}$-as well as other criminal laws ${ }^{41}-$ render conduct distant from the actual attempt of a crime punishable by law. To substantiate this argumentation, the BGH refers to $\S 80 \mathrm{StGB},{ }^{42}$ which criminalizes the preparation of a war of aggression. This is also entrenched in Article 26 (1) $2 \mathrm{GG}$. Therefore, rendering preparation acts criminally liable cannot be unconstitutional in general. ${ }^{43} \mathrm{In}$ addition, the Bundesverfassungsgericht decided in $1970^{44}$ that the legislature may

\footnotetext{
38 See Strafgesetzbuch [StGB] [German Penal Code], §§ 89a, para. 7, 49, para. 2, translation at http://www.gesetze-im-internet.de/englisch_stgb/index.html.

${ }^{39}$ See Judgment of May 8, 2014, supra note 2, at para. 3462.

${ }^{40}$ See Mitsch, supra note 11, at 211; see Zöller, supra note 35, at 377.

${ }^{41}$ See Judgment of May 8, 2014, supra note 2, at para. 3463 (detailing a list of similar statutes).

${ }^{42} / d$.

${ }^{43} / d$.

${ }^{44}$ See Bundesverfassungsgericht. [BVerfGE] [Federal Constitutional Court], 2 BvR 396/69, year, BVerfGE 28, para. 175 (referring to a previous version of $\S 100$ e StGB, which criminalized conduct that may endanger official secrets).
} 
criminalize actions in the earliest possible stages to alleviate any danger for state security. ${ }^{45}$ This decision was stated more precisely in several other judgements of the Bundesverfassungsgericht, ${ }^{46}$ in which the court ruled that new criminal laws can be justified if a valuable object of legal protection is endangered.

Thus, $\S 89$ a StGB can be rendered constitutional if it protects valuable rights of the individual or the public. The $B G H$ held that $\S 89$ a StGB might deter others from committing terrorist attacks and enables police and prosecutors to prevent any such offenses. This should subsequently protect the rights of individuals and the public more efficiently. ${ }^{47}$

Following this argumentation, the $B G H$ did not render the criminalization of the preparation of a crime to lead to the unconstitutionality of $\S 89$ a StGB. ${ }^{48}$ The BGH correctly ignored the critique in legal literature. ${ }^{49}$

\section{c) Unlawful Punishment of the Criminal's Attitude}

Furthermore, the $B G H$ held that $\S 89$ a StGB did not punish the attitude of the criminal, but rather perilous conduct. ${ }^{50}$ Otherwise, this would render $\S 89$ a StGB unconstitutional due to the fact that criminal law must not punish the thoughts of a person; instead it shall refer only to specific conduct. ${ }^{51}$ In the present case, the judges argue that the mens rea of $\S 89 a$ StGB comprises specific, precisely paraphrased conduct. ${ }^{52}$ Without this objective part, one cannot be convicted on the basis of this section. Therefore, the statute does not punish definite plans or attitudes; it relates, rather, to the specific conduct that imperils the rights of third parties or the public.

\footnotetext{
${ }^{45} / d$. at para. $186,188$.

${ }^{46}$ See [BVerfG] [Federal Constitutional Court], 2 BvR 869/92, 1993, NeUE JURISTISCHE WoCHENSCHRIFT [NJW] 1911, (regarding a previous version of $\S 180$ a StGB); see [BVerfG] [Federal Constitutional Court], 2 BvR 1656/03, 2006, [NVwZ] 583 (584), (regarding § 316b StGB).

${ }^{47}$ See Judgment of May 8, 2014, supra note 2, at para. 3463.

${ }^{48} / d$.

${ }^{49}$ See, e.g., Mitsch, supra note 11, at 211; see Zöller, supra note 35, at 377; see N. Gazeas, T. Grosse-Wilde \& A. Kießling Die neuen Tatbestände im Staatsschutzstrafrecht - Versuch einer ersten Auslegung der $\S 89 a, 89 b$ und 91 StGB, NSTZ 593, 604 (2009).

${ }^{50}$ See Judgment of May 8, 2014, supra note 2, at para. 3463.

${ }^{51}$ See W. Joecks, W. Joecks/K. Miebach, Münchener Kommentar zum StGB § 16 para. 20 (2nd ed. 2011).

${ }^{52}$ See Judgment of May 8, 2014, supra note 2, at para. 3463. But see Mitsch, supra note 11, at 211.
} 


\section{d) Constitutionality of the State Security Provision}

In the decision, the $B G H$ scrutinized the construction and constitutionality of the state security provision included in $\S 89 a$ (1) 2 StGB. This provision stipulates that the perpetrator's actions must be capable of impairing the existence or security of a state or of an international organization, or abolishing, robbing of legal effect or undermining constitutional principles of the Federal Republic of Germany. When considering the impairment of state security, those actions which precede the offense are relevant. As to the mens rea, intention thereto is required pursuant to the wording of the law.

In accordance with $\S 120$ (2) $1 G V G^{53}$, the $B G H$ submits a definition of the term state security-it refers to the internal and external security of the Federal Republic. Internal security means a state of relative invulnerability of its existence and its constitution from violent subversive acts of internal parties. Merely affecting any public feeling of security is not sufficient, but the impairment of state affairs is required. As a rule, the internal security is affected when an action can impair the internal structure of the state. This must be established objectively. Indicators of the requisite impairment of state security are: Public officials as victims, symbolism and publicity of the chosen location, and other circumstances of the offense.

According to the $B G H$, the perpetrator must only have knowledge of the relevant circumstances and accept the consequences hereof (dolus eventualis) ${ }^{54}$. This opinion diverges from a part of the legal literature which opines that it is further required that the perpetrator must have certain knowledge of the consequences caused by his act (seconddegree dolus directus). ${ }^{5556}$ The arguments of the $B G H$ therefore include the intent and purpose of the law as well as the pertinent legislative materials. ${ }^{57}$

Although the protected interest of the public feeling of state security is fairly vague, the $\mathrm{BGH}$ has no doubt that there is no excessive expansion of criminal prosecution and thus, deems the state security provision constitutional.

\footnotetext{
${ }^{53}$ Gerichtsverfassungsgesetz [GVB] [German Courts Constitution Act].

${ }^{54}$ Similar to a low level of recklessness.

${ }^{55}$ Similar to the second level of intent.

${ }^{56}$ See Sternberg-Lieben, supra note 25, at para. 17; see Paeffgen, supra note 30, at 25.

${ }^{57}$ See also construing the requisite mens rea below under subparagraph (e).
} 


\section{e) Constitutional Interpretation of the Mens Rea}

Finally, and equally important, the court elaborates on the question as to whether it is appropriate to convict a perpetrator who has not determined the time, place, and details of the later attack. ${ }^{58}$ According to the German Legislature, ${ }^{59}$ it shall be sufficient that one who prepares a terrorist attack has the intention to commit an offense against life ${ }^{60}$ or encroach upon the right to personal freedom. ${ }^{61}$

The court, however, held that this argumentation does not adhere to the systematic nature of the German criminal law: in order to be liable to criminal prosecution, it shall not suffice that one merely determines the general type of the offense. The conduct must be focused additionally on a severe danger to the existence or security of a state, pursuant to $\S 89 a$ (1) $2 \mathrm{StGB}$. Thus, the offense must be definite enough to ascertain whether the state is jeopardized. As a consequence, the perpetrator shall have the intention to commit one of the offenses mentioned in $\S 89$ a StGB as well as all further prerequisites. ${ }^{62}$ With regards to the time, place, and victims of the crime, neither the wording of $\S 89$ a StGB nor the justification of the legislator require a specific intention. ${ }^{63}$

Irrespective of this argumentation, one must consider that the law's scope is excessively broad and encompasses neutral behavior that is far from criminal - pursuant to § 89a StGB, it is sufficient that one obtains or stores inter alia objects or substances essential to produce weapons, explosives, poison, or similar substances detrimental to health. Hence, the actus reus would, for instance, be met if one purchases a significant number of flowers, which saps could theoretically be used to create poisonous substances-no matter the reason for which they were originally obtained. The same applies to other neutral conduct, such as the purchase of mobile phones or saving money ${ }^{64}$ Furthermore, a closer look into $\S 89$ a (2) No. 3 StGB-which refers to purchases of substances that could be utilized to produce inter alia weapons-reveals that the legislator even criminalizes the preparation

\footnotetext{
${ }^{58}$ See Judgment of May 8, 2014, supra note 2, at para. 3464.

${ }^{59}$ See supra note 21 , at 14 .

60 See Strafgesetzbuch [StGB] [German Penal Code], §§ 211-212, trans/ation at http://www.gesetze-iminternet.de/englisch_stgb/index.html (criminalizing the conduct under law).

${ }^{61}$ See Strafgesetzbuch [StGB] [German Penal Code], §§ 239a, 239b, translation at http://www.gesetze-iminternet.de/englisch_stgb/index.html (criminalizing the conduct under law).

${ }^{62}$ See OLG Karlsruhe [OLG], 2 Ws 157/11, StV 348, 350 (2012).

${ }^{63}$ See Judgment of May 8, 2014, supra note 2, at para. 3464; see Sternberg-Lieben, supra note 25, at para. 4.

64 See Gazeas, Grosse-Wilde \& Kießling, supra note 49, at 597; see R. Deckers \& J. Heusel Strafbarkeit terroristischer Vorbereitungshandlungen - rechtsstaatlich nicht tragbar, in ZRP 169, 171 (2008) (providing further examples of neutral behaviors which fulfill the actus reus).
} 
of the preparation. These examples exemplify that most of the conduct mentioned in $\S 89 a$ (2) StGB does not recessively feed into a terrorist attack. ${ }^{65}$ Many argue that this renders the statute inappropriate and subsequently unconstitutional. ${ }^{66}$

The court held, however, that the broad actus reus does not inevitably render § 89a StGB unconstitutional. The judges utilized the mens rea to curb the scope of the law-pursuant to $\S 89$ a StGB, the offender must at least approve of the consequences of the crime. The wording does not require the clear intention to commit a terrorist attack; it shall be sufficient that the perpetrator knows about the possibility of injuring people and accepts the effects. Thus, the requisite mens rea is nearly as broad as the actus reus. With regard to the high custodial sentence, this may afflict the individual in an inappropriate and unforeseeable way. ${ }^{67}$ To avoid the unconstitutionality of the section, however, the BGH construes the statute in the light of the constitution. ${ }^{68}$ According to this restrictive interpretation, the perpetrator must act with the clear intention to conduct a terrorist attack after the preparation (first-degree dolus directus) ${ }^{69}$. The intention must be proved at trial by the prosecution service. This restricts the scope of $\S 89$ a StGB in a considerable way. According to the judges, the law's wording and the legislature's justification do not contradict the restrictive construal. Furthermore, it is sufficient to render $\S 89$ a StGB constitutional.

It has to be honored that the court attempts to sustain the statute and invoke it in the case. With regards to the separation of power, the interpretation in light of the constitution seems generally sensible. According to legal literature, a critical analysis of why the court curtails the broad objective part of the statute by increasing the prerequisites for the subjective part is necessary. ${ }^{70}$

This $B G H$ solution might lead to contradictory and absurd results in a trial. First, aside from cases where the defendant confessed his intention, the mens rea has to be determined by examining the objective conduct of the defendant. ${ }^{71}$ Second, if the evidence does not approach the necessary standard to prove the defendant's intention to commit a terrorist

\footnotetext{
${ }^{65}$ See Zöller, supra note 35, at 377.

${ }^{66}$ See Gazeas, Grosse-Wilde \& Kießling, supra note 49, at 604; see Deckers \& Heusel, supra note 64, at 171; see Zöller, supra note 35 , at 378 .

${ }^{67}$ See Paeffgen, supra note 30, at 22.

${ }^{68}$ See Judgment of May 8, 2014, supra note 2, at para. 3464.

${ }^{69}$ Similar to the first level of intent.

${ }^{70}$ See Zöller, supra note 35, at 378; see Mitsch, supra note 11, at 211.

${ }^{71}$ See Mitsch, supra note 11, at 211.
} 
attack, he may be able to avoid prosecution by alleging that he was not sure whether to commit an attack or not. ${ }^{72}$

Hence, a restrictive interpretation of the broad actus reus in lieu of the mens rea could have been more effective. Notwithstanding, it is highly probable that lower courts will orient themselves towards the decision of the $B G H$ and invoke the statute without any concerns in their cases.

\section{Application to the Case}

\section{Actus Reus}

To meet the requirements of the actus reus, the defendant would have had to objectively prepare a serious act of violent subversion. According to $\S 89$ a StGB, such an act comprises a criminal offense against life ${ }^{73}$ or personal liberty ${ }^{74}$ that is intended and suitable to impair the existence or security of a state or to subvert the constitutional principles of the Federal Republic of Germany. The BGH found that the actus reus was satisfied.

By purchasing metal pipes, fireworks etc., the defendant obtained items and substances necessary for manufacturing pipe bombs, which qualify as contraptions denoted in $\S 89 a$ (2) No. 1, thus executing a part of the actus reus.

The defendant was determined to build this explosive device and detonate it in order to kill an unascertained number of people. Hence, instrumentalities, method of execution, an outline of circumstances, and the perpetrator's motivation were already definite. Although a specific time and place had not been determined, the act was already adequately substantiated.

Furthermore, the defendant intended the attack to be directed against random victims representing the Western world, at which the defendant's religious hatred was aimed. This attack could have sown seeds of doubt into the general public regarding the capability of the security authorities and therefore would have posed a threat to the domestic security of Germany.

\footnotetext{
72 See Zöller, supra note 35 , at 378.

73 See Strafgesetzbuch [StGB] [German Penal Code], §§ 211, 212, translation at http://www.gesetze-iminternet.de/englisch_stgb/index.html.

74 See Strafgesetzbuch [StGB] [German Penal Code], §§ 239a, 239 b translation at http://www.gesetze-iminternet.de/englisch_stgb/index.html.
} 


\section{Mens Rea}

Regarding the requirements of the violent act of subversion as well as the specific act itself, the defendant at least operated with conditional intent (dolus eventualis), which is sufficient in these cases. ${ }^{75}$

The explanations of the LG Frankfurt, however, were not adequate to substantiate the means rea concerning the execution of the prepared act. The judgment did not show sufficient grounds to presume the defendant's firm determination to commit the offense. Consequently, the $\mathrm{BGH}$ reversed the conviction and relegated the case for a retrial.

\section{Voluntary Self-Exclusion of a Judge Due to Conflict of Interest}

In German law, § 24 (2) of the Code of Criminal Procedure (StPO) ${ }^{76}$ permits parties in criminal cases to challenge and remove a judge assigned to hear the case if it can be established that the judge is biased or has a conflict of interest. In general, the fact that a judge has expressed an opinion on a case is not sufficient cause for a judge's recusal. Although, a judge who has already chosen a final position concerning the decisive issue of the case in question cannot be unbiased. This challenge procedure received considerable attention in the criminal appeal at hand.

The problems associated with the challenge procedure-which is often used as a defense delay tactic-are that it greatly disrupts calendars and defers the commencement of criminal trials. In this particular case, however, it was not the defense, but one of the judges who recused himself-which occurred for the first time at the Federal Court of Justice-and invoked a remarkable justification. The judge stated that he was interested in chemical and physical issues as well as Islam and theological statements of a former member of al-Qaeda. The judge argued that these very interests were sufficient to commit the offense sanctioned by $\S 89$ a StGB. ${ }^{77}$ Therefore, his personal interest in interpreting this prescription rather restrictively, he believed, made him biased not to the detriment but, on the contrary, to the benefit of the defendant.

This illustrates the controversial nature of $\S 89$ a StGB once more, as its broad actus reus is deemed unconstitutional by many voices among jurisprudence.

\footnotetext{
${ }^{75}$ See Schäfer, supra note 26, at 57.

${ }^{76}$ Strafprozessordnung [StPO] [Code of Criminal Procedure].

${ }_{77}$ See Bundesgerichtshof [BGH] [Federal Court of Justice] April 2, 2014, 3 StR 243/13 [BeckRS] 05923 para. 2.
} 


\section{Conclusion}

Even though the constitutionality of $\S 89$ a StGB is highly controversial, the $B G H$ concluded that the section is constitutional when interpreted in line with constitutional principles. It found that the wording of the section is in line with the principle of legal certainty. Furthermore, $\S 89$ a StGB was found to be suitable to serve a legitimate legislative purpose and to be an appropriate measure for it. It is the court's opinion that the rather broad actus reus is curbed by a restrictive interpretation of the mens rea, rendering $\S 89$ a StGB constitutional.

While the final word on the constitutionality of $\S 89$ a StGB is yet to be spoken by the Bundesverfassungsgericht, the German legislature already amended the section by adding subsection 2a. ${ }^{78}$ This subsection criminalizes the act of leaving Germany in order to receive instructions for the preparation of a serious violent offense endangering the state in a foreign country. In other words, it criminalizes the "preparation of a preparation" 79 of a serious violent offense. As this shifts the criminal liability to a very early stage, this subsection is even more controversial than the rest of the section. ${ }^{80}$ In light of the increasing threat of terrorist attacks in (central) Europe, however, and the global call for a more efficient prosecution of terrorists, ${ }^{81}$ it is likely the Bundesverfassungsgericht will deem $\S 89$ a StGB to be in line with the constitution-including subsection $2 a$.

\footnotetext{
${ }^{78}$ See Regierungsentwurd [Cabinet Draft] Deutscher Bundestag: Druckashen [BT] 18/4087.

79 See J. Puschke, Der Ausbau des Terrorismusstrafrechts und die Rechtsprechung des Bundesgerichtshof, STV 457, 459 (2015).

${ }^{80}$ See S. Beukelmann, Neues im Kampf gegen den Terror, NJW-SPEZIAL 2015 120f; see Puschke, supra note 79, at 459; see M. Zöller, Der Terrorist und sein (Straf-)Recht 90, 103 (GA, 2016); see N. Gazeas, Zu viel des Guten? - Zur Verschärfung im Terrorismusstrafrecht, in DRIZ 218, 220 (2015).

${ }^{81}$ See, e.g., U.N. Res. 2178 (2014).
} 